\title{
Laporan PBL I di Wilayah Pesisir Desa Bajo Indah Kecamatan Soropia Kabupaten Konawe
}

\author{
Universitas Islam Negeri Alauddin Makassar \\ Resqy Rhaudatul Jannah \\ Email : khikyri26@gmail.com
}

\section{- Proses Pemecahan Masalah}

1) Persiapan

Dalam PBL ini dilakukan di Wilayah Pesisir Desa Bajo Indah di Kec. Soropia. Permasalahan yang dihadapi di Desa Bajo Indah Kec. Soropia Kab. Konawe merupakan wilayah pesisir yang penduduknya berjumlah 682 orang. Letak desa yang berada di daerah pesisir sehingga penduduk tidak memiliki fasilitas sanitasi yang layak. Banyak masyarakat yang BAB menggunakan jamban cemplung yang tidak memiliki septik tank dan dapat mencemari sumber air.

2) Perencanaan

Kegiatan ini dilaksanakan dalam 2 (dua) tahap, yaitu tahap pertama dilakukan penyuluhan atau sosialisasi kepada masyarakat setempat dengan tema: "Ciptakan Lingkungan Bersih dan Sehat melalui Pembangunan Septic Tank Komunal sebagai Upaya Pencegahan Penularan Penyakit di Wilayah Pesisir", kemudian dilanjutkan dengan sesi tanya jawab. Tahap kedua adalah pembuatan septic tank komunal sebagai percontohan, untuk memenuhi syarat jamban sehat.

3) Pelaksanaan

Pembuatan septic tank komunal yaitu, pertama-tama dilakukan penentuan lokasi; kedua, menyiapkan bahan; kemudian proses penggalian septic tank hingga mencapai kedalaman kurang lebih $30 \mathrm{~cm}$, tinggi cincin $50 \mathrm{~cm}$, luas diameternya $80 \mathrm{~cm}$. Lubang yang telah ada kemudian dimasukan cincin yang sudah disesuaikan dengan besarnya lubang galian. Setelah itu, dilakukan penutupan lubang menggunakan penutup cincin yang sudah disediakan, dan terakhir dilakukan proses pemasangan pipa dari kloset ke lubang septic tank.

4) Pemantauan

- Kegiatan penyuluhan atau sosialisasi dilakukan pada tanggal 15 Februari 2020, pukul 16.30 wita, bertempat di Balai Pertemuan Desa Bajo Indah, dan dihadiri oleh 23 orang warga Desa Bajo Indah yang terdiri dari salah seorang petugas puskesmas, kepala dusun, serta warga dusun 1, 2, dan 3.

- Septic tank yang di buat berjumlah 1 unit yang akan digunakan oleh tiga rumah. Peran masyarakat cukup tinggi, dimana dalam pembuatan septic tank ini masyarakat Desa Bajo Indah yang turun langsung dalam proses pembuatannya.

\section{5) Evaluasi}

Warga Desa Bajo Indah masih ada yang memiliki pemahaman kurang tentang pentingnya fasilitas jamban sehat, dan dampak yang akan ditimbulkan akibat tidak tersedianya jamban yang memenuhi syarat kesehatan pada rumah tangga.

Kurangnya pengetahuan warga Desa Bajo Indah tentang pentingnya memiliki jamban yang memenuhi syarat kesehatan, sehingga warga telah terbiasa 
menggunakan jamban yang tidak memenuhi syarat seperti diantaranya jamban yang tidak mempunyai septic tank sehingga warga lebih memilih untuk buang air besar di tempat-tempat terbuka, dan lebih memilih membuang air besar menggunakan jamban cemplung. Faktor pendorong lainnya yang membuat warga harus menggunakan jamban cemplung adalah faktor ekonomi yang tidak mencukupi untuk pembuatan jamban yang memenuhi syarat di rumah mereka.

\section{6) Perluasan}

Adanya bangunan tangki septik (septic tank) dalam skala komunal sangat efektif untuk menurunkan tingkat pencemaran dan melindungi ekosistem perairan. Perencanaan tangki septik komunal sebagai wujud dari intalasi pengolahan air limbah dalam skala kecil merupakan elemen yang sangat esensial untuk memperlancar sanitasi masyarakat dalam mempertahankan stabilitas ekosistem lingkungan.

Selain itu juga dilakukan pengabdian masyarakat, berupa pemberian penyuluhan atau sosialisasi terkait septic tank serta pembangunan septic tank komunal sebagai percontohan bagi warga Desa Bajo Indah, maka dapat diketahui bahwa warga telah memperoleh pemahaman, sehingga dapat meningkatkan kesadaran warga tentang jamban sehat. 


\section{Daftar Pustaka}

Anonim.(2016).https://bontang.prokal.co/read/news/8013-bangun-septictank-komunalcegahpencemaran-laut-dari-limbahrumah-tangga.

Asep Sapei, dkk. (2011). Desain instalasi pengolah limbah WC komunal Masyarakat pinggir sungai Desa Lingkar Kampus. Jurnal Ilmu Pertanian Indonesia, Vol. 16 No.2. hlm. 91-99

Laporan PBL I 2019. Desa Bajo Indah Kecamatan Soropia.

Sudarmaji, Hamdi. (2013). Tangki Septik dan Peresapannya Sebagai Sistem Pembuangan Air Kotor di Permukiman Rumah Tinggal Keluarga. Teknik Sipil.Vol 9(2):134142. 